\title{
PENGARUH MODEL PEMBELAJARAN KOOPERATIF TIPE GROUP INVESTIGATION BERBANTUAN MEDIA VIRTUAL LABORATORY TERHADAP HASIL BELAJAR IPA SISWA
}

\author{
Nur Halimah, Ketut Suma, Putri Sarini \\ Program Studi S1 Pendidikan IPA \\ Universitas Pendidikan Ganesha \\ Singaraja, Indonesia \\ e-mail: \{nur.halimah, ketut.suma, putri.sarini\}@undiksha.ac.id
}

\begin{abstract}
ABSTRAK
Penelitian ini bertujuan untuk mendeskripsikan dan menjelaskan perbedaan hasil belajar IPA antara siswa yang dibelajarkan dengan model pembelajaran kooperatif tipe Group Investigation berbantuan media virtual laboratory dan model pembelajaran Direct Instruction. Penelitian ini merupakan penelitian eksperimen semu (quasi experiment) dengan rancangan non-equivalent pretest-posttest control group design. Populasi penelitian ini adalah seluruh siswa kelas VIII MTs Negeri 2 Buleleng tahun ajaran 2017/2018 yang berjumlah 80 siswa yang tersebar ke dalam 4 kelas. Pengambilan sampel dilakukan dengan teknik simple random sampling untuk memperoleh 2 kelas sebagai kelas eksperimen dan 2 kelas sebagai kelas kontrol. Data hasil belajar dikumpulkan melalui tes pilihan ganda diperluas sebanyak 20 item, dengan reliabilitas sebesar 0,883. Data dianalisis menggunakan statistik deskriptif dan Anakova satu jalur dengan taraf signifikansi 5\%, kemudian dilakukan uji lanjut yaitu uji signifikansi skor rata-rata antar kelompok yang menggunakan Least Significant Difference (LSD). Hasil penelitian menunjukkan terdapat perbedaan hasil belajar IPA antara siswa yang dibelajarkan dengan model pembelajaran Group Investigation berbantuan media virtual laboratory dan model pembelajaran Direct Instruction. Rata-rata skor hasil belajar IPA antara siswa yang belajar dengan model pembelajaran Group Investigation berbantuan media virtual laboratory lebih tinggi dibandingkan dengan rata-rata skor hasil belajar IPA yang belajar dengan model pembelajaran Direct Instruction.
\end{abstract}

Kata Kunci : Group Investigation, Virtual Laboratory, Hasil Belajar

\begin{abstract}
This study was aimed to describe and explain the difference of science learning outcomes between students who were taught by cooperative learning model type Group Investigation assisted by virtual laboratory media and Direct Instruction learning model. This study is a quasi experiment with non equivalent pretestposttest control group design. The population of this study is all students of class VIII MTs Negeri 2 Buleleng academic year 2017/2018 which amounted to 80 students spread into 4 classes. Sampling is done by simple random sampling technique to get 2 classes as experiment class and 2 class as control class. The data of learning outcomes was collected through multiple choice test with written justification by 20 items, with reliability of 0.883. Data were analyzed using descriptive statistics and Anacova one lane with significance level of $5 \%$, then further test was test of significance of mean scores between groups using Least Significant Difference (LSD). The results showed that there was a difference of science learning outcomes between students who were taught by Group Investigation modeled assisted by virtual laboratory media and Direct Instruction learning model. The average score of science learning outcomes between students taught with Group Investigation modeled with virtual laboratory media is higher than the average score of learning outcomes of IPA taught with Direct Instruction learning model.
\end{abstract}

Keywords : Group Investigation, Virtual Laboratory, Learning Outcomes 


\section{PENDAHULUAN}

Pendidikan memiliki peranan yang sangat penting dalam kehidupan berbangsa dan bernegara, yaitu untuk menjamin kelangsungan hidup dan perkembangan bangsa itu sendiri. Hal ini sebagaimana tercantum dalam Undang-Undang Nomor 20 tahun 2003 tentang Sistem Pendidikan Nasional (2003:3) pasal 1 yang berbunyi: "Pendidikan adalah usaha sadar dan terencana untuk mewujudkan suasana belajar dan proses pembelajaran agar peserta didik secara aktif mengembangkan potensi dirinya untuk memiliki kekuatan spiritual keagamaan, pengendalian diri, kepribadian, kecerdasan, akhlak mulia, serta keterampilan yang diperlukan dirinya, masyarakat, bangsa, dan negara" (Depdiknas, 2003).

Berdasarkan pernyataan tersebut, jelas terlihat bahwa pendidikan merupakan tanggung jawab setiap orang, termasuk pemerintah. Pemerintah Indonesia telah melakukan berbagai upaya untuk meningkatkan mutu pendidikan, salah satunya, penyempurnaan kurikulum dari Kurikulum Tingkat Satuan Pendidikan (KTSP) menjadi Kurikulum 2013. Peran guru dalam KTSP berbeda dengan peran guru pada Kurikulum 2013. Pada KTSP, guru dituntut untuk mengembangkan komponenkomponen kurikulum secara mandiri yang dikembangkan dalam bentuk silabus. Pada Kurikulum 2013, guru hanya bertugas untuk mengimplementasikan kurikulum. Berkurangnya tugas guru dalam Kurikulum 2013 menjadikan peran guru lebih optimal dalam pembelajaran, yaitu sebagai sumber belajar, fasilitator, pengelola, demonstrator, pembimbing, motivator, dan evaluator (Alawiyah, 2013).

Peran siswa lebih dominan pada Kurikulum 2013 ini sehingga Kurikulum 2013 dikatakan bersifat student center atau berpusat pada siswa. Adapun tujuan Kurikulum 2013 adalah untuk mempersiapkan masyarakat Indonesia agar memiliki kemampuan hidup sebagai pribadi dan warga negara yang beriman, produktif, kreatif, inovatif, dan afektif serta mampu berkontribusi pada kehidupan bermasyarakat, berbangsa, dan bernegara.

Pemerintah dalam Kurikulum 2013 mengamanatkan bahwa mata pelajaran IImu Pengetahuan Alam (IPA) SMP/MTs dikembangkan sebagai mata pelajaran integrative science; berorientasi aplikatif; mengembangkan kemampuan berpikir, kemampuan belajar, rasa ingin tahu, dan sikap peduli, serta tanggung jawab terhadap lingkungan alam. IPA merupakan ilmu pengetahuan yang sistematis dan menyeluruh. IImu pengetahuan tentang alam semesta merupakan ilmu pengetahuan yang holistik, bukan merupakan ilmu yang parsial antara Kimia, Fisika, dan Biologi. Oleh karena itu, IPA harus diselenggarakan secara terpadu. Sebagaimana dianjurkan dalam Permendiknas nomor 22 tahun 2006, model pembelajaran IPA sebaiknya dilaksanakan secara terpadu terutama pada jenjang pendidikan dasar, mulai dari tingkat sekolah dasar (SD/MI) sampai sekolah menengah pertama (SMP/MTs) (Depdiknas,2006).

Upaya tersebut seyogyanya mampu meningkatkan kualitas pendidikan. Namun, kenyataannya banyak siswa yang masih mengalami kesulitan dalam belajar sehingga berdampak pada hasil belajar yang rendah. Hal ini dikarenakan materi yang diterima siswa bersifat abstrak dan kurangnya ketertarikan siswa terhadap pembelajaran IPA. Siswa hanya menghafal materi dan kurang mampu menggunakan konsep jika menemukan masalah dalam kehidupan sehari-hari yang berhubungan dengan konsep tersebut.

Hal tersebut diperkuat oleh hasil penelitian tentang penilaian motivasi hasil belajar level international yang dilakukan oleh OECD (Organization for Economic Cooperational Development) melalui PISA (Programme for International Student Assessment) pada tahun 2015. Indonesia berada pada peringkat ke-62 dari 70 negara untuk skor Sains dan Matematika. Indonesia memiliki rerata skor yang masih rendah dari batas rerata OECD yaitu 403 poin dari 490 poin (OECD, 2016). Selain itu, hasil 
penelitian TIMSS (The Trends in International Mathemathics and Science Study) tahun 2011 menempatkan Indonesia pada peringkat 38 dari 45 negara dan tahun 2015 menempatkan Indonesia pada peringkat 45 dari 50 negara dengan skor 397 (Balitbang, 2015). Hasil penelitian tersebut menunjukkan rendahnya kualitas pendidikan di Indonesia sehingga perlu diadakan perbaikan guna meningkatkan kualitas pendidikan di Indonesia. Salah satunya, pada mata pelajaran IPA.

Masalah senada juga ditemui pada rata-rata nilai hasil Ujian Nasional (UN) IPA tingkat SMP/MTs di Kabupaten Buleleng. Dari hasil rekapitulasi Kemendikbud Kabupaten Buleleng, terlihat bahwa tahun 2014 rata-rata nilai UN IPA sebesar 74,40; tahun 2015 hanya sebesar 54,13; tahun 2016 mengalami peningkatan menjadi 58,11 ; sedangkan pada tahun 2017 mengalami penurunan drastis sebanyak 7,66 poin menjadi 50,45 (Kemdikbud, 2017). Fakta ini menunjukkan bahwa kompetensi IPA yang dimiliki siswa masih rendah sehingga perlu adanya perbaikan proses pembelajaran agar kualitas pendidikan Indonesia juga meningkat.

Banyak faktor yang menyebabkan rendahnya hasil belajar siswa pada pelajaran IPA. Menurut Muhibbin (2005), faktor-faktor tersebut antara lain faktor internal dan eksternal siswa. Faktor internal meliputi intelegensi, sikap, bakat, minat, dan motivasi siswa. Faktor eksternalnya ialah peran guru serta sarana dan prasarana di sekolah. Sebagai pengelola pembelajaran, guru harus mampu mengorganisasi dan menggali potensi-potensi yang berperan untuk meningkatkan hasil belajar siswa. Guru perlu menyusun strategi pembelajaran agar siswa dapat menggunakan keterampilannya pada saat proses belajar mengajar berlangsung untuk meningkatkan hasil belajar siswa.

Salah satu penyebab rendahnya hasil belajar siswa adalah masih diterapkannya metode pembelajaran yang bersifat teacher center, yaitu guru yang terlebih dahulu mendemonstrasikan pengetahuan atau keterampilan yang akan dilatihkan kepada siswa secara keseluruhan sehingga siswa dalam mengembangkan kemampuannya masih sangat terbatas. Selain itu, guru juga jarang melakukan praktikum di laboratorium karena minimnya sarana dan prasarana yang dimiliki sekolah. Guru masih menerapkan pola konvensional dalam proses pembelajaran, yaitu dengan menggunakan metode ekspositori atau yang lebih dikenal dengan model pembelajaran langsung (direct instruction). Hal ini menyebabkan penguasaan serta pemahaman konsep IPA siswa rendah terutama dalam hal melakukan prosedur ilmiah. Proses pembelajaran juga kurang membangkitkan motivasi dan aktivitas siswa. Hal tersebut mengindikasikan bahwa kualitas pembelajaran IPA di sekolah masih rendah. Kualitas pembelajaran yang rendah tentunya akan berdampak pada rendahnya hasil belajar IPA siswa.

Rendahnya hasil belajar siswa menunjukkan adanya masalah pada proses pembelajaran. Sanjaya (2012) menyatakan bahwa salah satu masalah yang dihadapi dunia pendidikan Indonesia saat ini adalah lemahnya proses pembelajaran. Proses pembelajaran hingga dewasa ini masih didominasi guru dan kurang memberikan akses bagi peserta didik untuk berkembang secara mandiri melalui penemuan dalam proses berpikirnya. Hal ini berlaku untuk semua mata pelajaran, termasuk IPA. Oleh karena itu, perlu dilakukan inovasi dalam proses pembelajaran. Salah satunya adalah dengan menggunakan model-model pembelajaran yang inovatif.

Berbagai inovasi dalam pendidikan IPA telah dilakukan dalam kurun waktu terakhir ini. Hal ini merupakan upaya untuk mengoptimalkan siswa dalam belajar. Salah satu model pembelajaran yang bisa digunakan untuk meningkatkan hasil belajar, membuat pembelajaran menjadi menyenangkan karena membangkitkan motivasi dan aktivitas siswa, serta mengembangkan sikap bekerja sama adalah model pembelajaran kooperatif (Slavin, 2006). Pembelajaran kooperatif mencerminkan pandangan bahwa manusia belajar dari pengalaman mereka dan berpartisipasi aktif dalam kelompok kecil yang membantu siswa belajar keterampilan sosial bersamaan juga dengan membantu 
siswa dalam meningkatkan hasil belajar. Pembelajaran kooperatif menekankan pada siswa untuk belajar bersama sebagai suatu tim dalam menyelesaikan tugas-tugas kelompok untuk mencapai tujuan bersama sehingga setiap anggota kelompok memiliki tanggung jawab yang sama untuk keberhasilan kelompoknya (Slavin, 2006).

Model pembelajaran kooperatif tipe Group Investigation (GI) merupakan salah satu model pembelajaran kooperatif yang efektif untuk membuat variasi suasana diskusi yang mempengaruhi pola interaksi siswa dalam pembelajaran. Prosedur yang digunakan dalam Gl dapat memaksimalkan kegiatan belajar siswa dengan memanfaatkan kelompok-kelompok kecil (Isjoni, 2009). Model pembelajaran ini dirancang untuk mengatasi kesulitan belajar siswa secara individual. Dalam sintaksnya, GI menekankan pada kemampuan investigasi atau penyelidikan siswa terhadap suatu permasalahan melalui praktikum atau percobaan untuk mencari atau memahami informasi sehingga dapat digunakan untuk memecahkan suatu masalah.

Salah satu materi pembelajaran yang sesuai dengan karakteristik model pembelajaran $\mathrm{Gl}$ adalah materi tekanan pada zat dan penerapannya dalam kehidupan sehari-hari. Materi tersebut memerlukan pembuktian melalui kegiatan praktikum sehingga siswa tidak hanya berimajinasi tentang bagaimana tekanan dapat mempengaruhi bentuk dan kedudukan suatu zat serta penerapan konsep tekanan zat dalam kehidupan sehari-hari, tetapi juga dapat menemukan konsep yang jelas melalui proses penyelidikan.

Agar proses penyelidikan dalam sintaks model pembelajaran GI dapat berjalan optimal, idealnya guru mengajak siswa melakukan investigasi melalui praktikum atau percobaan. Pembelajaran IPA, khususnya materi tekanan pada zat dan penerapannya dalam kehidupan sehari-hari, sangatlah banyak memuat submateri yang perlu dipraktikumkan. Namun, keterbatasan alat dan bahan yang tersedia di laboratorium sekolah tak jarang mengakibatkan kegiatan praktikum tidak dapat dilakukan sehingga proses pembelajaran menjadi terhambat.
Media pembelajaran sangat diperlukan untuk mengatasi keterbatasan tersebut. Media yang dibutuhkan adalah media yang berfungsi secara efektif, efisien, dan dapat menjadi alternatif pengganti peran laboratorium nyata di sekolah. Salah satu inovasi di bidang teknologi pendidikan yang menjawab keterbatasan peran laboratorium nyata yaitu media virtual laboratory. Praktikum yang dilakukan secara virtual artinya praktikum atau percobaan yang dilakukan secara tidak nyata, tetapi dibantu komputer yang telah terinstall software yang siap dioperasikan.

Media virtual laboratory dapat digunakan untuk mentransfer pengetahuan baik konseptual maupun prosedural. Media ini menjadi solusi terbaik untuk melakukan praktikum secara "real time" kapanpun dan dimanapun kegiatan praktikum dilakukan (Kurnia, 2017). Agar kegiatan praktikum dapat berjalan dengan baik, penggunaan media virtual laboratory juga dilengkapi dengan petunjuk penggunaan media virtual laboratory dan lembar kerja peserta didik (LKPD). Dengan begitu, diharapkan penggunaan media virtual laboratory dapat membantu keberhasilan model pembelajaran Gl dalam rangka meningkatkan hasil belajar siswa.

Beberapa penelitian yang telah dilakukan menunjukkan bahwa model pembelajaran GI berbantuan media virtual laboratory dapat meningkatkan hasil belajar IPA siswa. Penelitian Kurnia (2017) menunjukkan terdapat peningkatan kompetensi pengetahuan IPA siswa setelah diberi perlakuan menggunakan model pembelajaran kooperatif tipe Gl dengan penggunaan virtual laboratory dibandingkan dengan sebelum diberi perlakuan. Selanjutnya, penelitian Nisrina (2016), menunjukkan adanya peningkatan penguasaan konsep Fisika siswa dari aspek kognitif $\mathrm{C}_{1}$ sampai $\mathrm{C}_{5}$ yang dipengaruhi secara signifikan oleh model pembelajaran kooperatif dengan media virtual, sedangkan untuk aspek $\mathrm{C}_{6}$ peningkatannya lebih dipengaruhi oleh model pembelajaran langsung. Penelitian Maryani (2010), menyatakan bahwa metode pembelajaran kooperatif Gl berbantuan media laboratorium 
virtual dilengkapi handout dapat meningkatkan kualitas proses dan hasil belajar Kimia materi pokok laju reaksi.

Berdasarkan kajian teori tersebut, terlihat bahwa model pembelajaran kooperatif tipe GI berbantuan media virtual laboratory menunjukkan efektivitas yang besar terhadap peningkatan hasil belajar siswa dibandingkan dengan model pembelajaran Direct Instruction. Dengan demikian, peneliti merasa perlu dan penting untuk melakukan penelitian lebih lanjut sebagai pendukung terhadap penelitian terdahulu tentang pengaruh model pembelajaran kooperatif tipe Gl berbantuan media virtual laboratory terhadap hasil belajar IPA siswa kelas VIII.

\section{METODE PENELITIAN}

$$
\text { Penelitian ini merupakan }
$$
penelitian quasi experiment (eksperimen semu) dengan rancangan non-equivalent pretest-posttest control group design. Desain penelitian dapat digambarkan sebagai berikut:<smiles>O=[W]O[Na]</smiles>

(Diadaptasi dari Sugiyono, 2013)

Populasi dalam penelitian ini adalah seluruh siswa kelas VIII MTs Negeri 2 Buleleng tahun ajaran 2017/2018 yang berjumlah 80 siswa yang terdistribusi kedalam 4 kelas yaitu kelas VIII A, B, C dan D. Sampel penelitian dipilih menggunakan teknik Simple Random Sampling dan nantinya akan terpilih 2 kelas sebagai kelas eksperimen yang akan mendapat perlakuan dengan model pembelajaran kooperatif GI

\section{Tabel 1.}

berbantuan media virtual laboratory, sedangkan 2 kelas lagi sebagai kelompok kontrol yang akan mendapat perlakuan dengan model pembelajaran konvensional yang menggunakan model pembelajaran langsung (Direct Instruction).

Data yang diperoleh dalam penelitian ini adalah data kuantitatif yang berupa hasil posttes dalam bentuk pilihan ganda diperluas, dengan koefisien reliabilitas sebesar 0,883 . Metode dan teknik analisis data yang digunakan dalam penelitian ini adalah statistik deskriptif dan statistik inferensial

Analisis statistik inferensial yang digunakan adalah analisis kovariat (Anakova) satu jalur untuk menguji hipotesis yang diajukan dalam penelitian ini, karakteristik tes dalam penelitian ini memiliki konsistensi internal butir 0,347 hingga 0,743, memiliki reliabilitas sebesar 0,883 , dan indeks kesukaran butir 0,31 sampai 0,70. Sebelum dilaksanakan uji hipotesis, data yang diperoleh harus memenuhi beberapa asumsi, yakni uji normalitas, uji homogenitas, dan uji linearitas. Sebagai tindak lanjut Anakova dalam penelitian ini dilakukan uji signifikansi nilai rata-rata antar kelompok yang menggunakan Least Significant Difference (LSD). Semua taraf signifikansi yang digunakan dalam uji ini sebesar 0,05. Uji ini memanfaatkan bantuan SPSS 16.0 for Windows.

\section{HASIL PENELITIAN}

Skor rata-rata dan standar deviasi pretest-posttest siswa untuk masing-masing kelas disajikan pada Tabel 1.

Skor Rata-rata dan Standar Deviasi Pretest dan Posttest Siswa

\begin{tabular}{lcccc}
\hline \multirow{2}{*}{ Kelas } & \multicolumn{2}{c}{ Mean (M) } & \multicolumn{2}{c}{ Standar Deviasi } \\
\cline { 2 - 5 } & Pretest & Posttest & Pretest & Posttest \\
\hline Eksperimen & 49,38 & 80,17 & 6,342 & 8,674 \\
\hline Kontrol & 48,96 & 73,67 & 5,971 & 9,187 \\
\hline
\end{tabular}

Berdasarkan Tabel 1 dapat diketahui bahwa skor rata-rata pretest kelompok siswa pada kelas eksperimen yang mendapat perlakuan model pembelajaran kooperatif tipe Gl berbantuan virtual laboratory memiliki skor rata-rata $(M)=49,38$ dengan kualifikasi sangat kurang dan standar deviasinya (SD) $=6,342$. Skor rata-rata pretest kelompok siswa pada kelas kontrol yang mendapat perlakuan model pembelajaran Direct 
Instraction memiliki skor rata-rata $(\mathrm{M})=48,96$ berada pada kualifikasi sangat kurang dengan standar deviasi (SD) $=5,971$.

Skor postest kelompok siswa pada kelas eksperimen yang mendapat perlakuan model pembelajaran kooperatif tipe GI berbantuan virtual laboratory memiliki skor rata-rata $(M)=80,17$ berkualifikasi baik dan standar deviasinya (SD) $=8,674$. Skor postest kelompok siswa pada kelas kontrol

Tabel 2.

yang mendapat perlakuan model pembelajaran Direct Instraction memiliki skor rata-rata $(M)=73,67$ berada pada kualifikasi cukup baik dengan standar deviasi $(S D)=$ $9,187$.

Selain skor rata-rata dan standar deviasi, hasil penelitian ini juga menunjukkan distribusi frekuensi skor pretest dan posttest siswa untuk masing-masing kelas yang disajikan pada Tabel 2.

Distribusi Frekuensi Skor Pretest dan Posttest Siswa

\begin{tabular}{rccccc}
\hline \multirow{2}{*}{ Nilai } & \multirow{2}{*}{ Kualifikasi } & \multicolumn{3}{c}{ Frekuensi Sebaran Skor Siswa (\%) } \\
\cline { 3 - 6 } & & \multicolumn{2}{c}{ Kelas Eksperimen } & \multicolumn{2}{c}{ Kelas Kontrol } \\
\cline { 3 - 6 } & & Pretest & Posttest & Pretest & Posttest \\
\hline $90-100$ & Sangat Baik & - & 12,5 & - & 10,0 \\
\hline $80-89$ & Baik & - & 35,0 & - & 25,0 \\
\hline $65-79$ & Cukup & - & 47,5 & - & 55,0 \\
\hline $55-64$ & Kurang & 22,5 & 5,0 & 20,0 & 10,0 \\
\hline $0-54$ & Sangat & 77,5 & - & 80,0 & - \\
& Kurang & & & & \\
\hline
\end{tabular}

Berdasarkan Tabel 2 diketahui bahwa skor pretest siswa pada kelas eksperimen hanya terdistribusi pada kualifikasi kurang dan sangat kurang. Sedangkan distribusi frekuensi skor pada posttest siswa pada kelas eksperimen ini mengalami pergeseran kearah yang positif, yaitu sebanyak $12,5 \%$ siswa memiliki hasil belajar dengan kualifikasi sangat baik, 35\% siswa memiliki hasil belajar dengan kualifikasi baik, 47,5\% siswa memiliki hasil belajar pada kualifikasi cukup baik, dan 5\% siswa memiliki hasil belajar pada kualifikasi kurang. Tidak ada satupun siswa yang mendapat skor dengan kualifikasi sangat kurang.

Distribusi frekuensi skor pretest siswa pada kelas kontrol juga tidak jauh berbeda dari kelas eksperimen, yaitu tidak ada satupun siswa yang mendapat skor dengan kualifikasi sangat baik, baik dan cukup baik. Sedangkan distribusi frekuensi skor posttest siswa pada kelas kontrol ini siswa lebih dominan mendapatkan skor yang berkualifikasi cukup baik, sisanya sebanyak $10 \%$ siswa memiliki hasil belajar dengan kualifikasi sangat baik, 25\% siswa memiliki hasil belajar dengan kualifikasi baik, dan 10\% siswa memiliki hasil belajar pada kualifikasi kurang.

Berdasarkan hasil-hasil temuan ini, dapat disimpulkan bahwa skor rata-rata pretest pada kelas eksperimen hampir sama dengan skor rata-rata pretest pada kelas kontrol, dan skor rata-rata posttest hasil belajar IPA siswa pada kelas eksperimen lebih tinggi dibandingkan dengan kelas kontrol. Distribusi frekuensi skor pretest dan posttest yang dimiliki kelas eksperimen juga lebih baik dibandingkan kelas kontrol.

Uji asumsi prasyarat dilakukan sebelum uji hipotesis. Hasil uji asumsi menunjukkan semua sebaran data berdistribusi normal, varians antar kelompok homogen, hubungan antara variabel kovariat dan variabel terikat linear, dan tidak ada interaksi antara variabel kovariat dan variabel bebas. Sehingga uji Anakova satu jalur dapat dilanjutkan. Adapun hasil uji hipotesis yang diperoleh disajikan pada Tabel 3. 
Tabel 3. Hasil Uji Hipotesis

Dependent Variable: HasilBelajar

\begin{tabular}{|c|c|c|c|c|c|c|c|c|}
\hline Source & $\begin{array}{l}\text { Type III } \\
\text { Sum of } \\
\text { Squares }\end{array}$ & $D f$ & $\begin{array}{l}\text { Mean } \\
\text { Square }\end{array}$ & $F$ & Sig. & $\begin{array}{l}\text { Partial Eta } \\
\text { Squared }\end{array}$ & $\begin{array}{l}\text { Noncent. } \\
\text { Parameter }\end{array}$ & $\begin{array}{c}\text { Observe } \\
d \\
\text { Powerb }\end{array}$ \\
\hline $\begin{array}{l}\text { Corrected } \\
\text { Model }\end{array}$ & $1164.187 a$ & 2 & 582.094 & 7.210 & .001 & 158 & 14.421 & .926 \\
\hline Intercept & 6009.242 & 1 & $\begin{array}{r}6009.24 \\
2 \\
\end{array}$ & 74.435 & .000 & .492 & 74.435 & 1.000 \\
\hline $\begin{array}{l}\text { Pengetahuan } \\
\text { Awal }\end{array}$ & 31.675 & 1 & 31.675 & .392 & .533 & .005 & .392 & .095 \\
\hline $\begin{array}{l}\text { Model } \\
\text { Pembelajara } \\
n\end{array}$ & 1118.881 & 1 & $\begin{array}{r}1118.88 \\
1\end{array}$ & 13.859 & .000 & .153 & 13.859 & .957 \\
\hline Error & 6216.300 & 77 & 80.731 & & & & & \\
\hline Total & 460235.000 & 80 & & & & & & \\
\hline $\begin{array}{l}\text { Corrected } \\
\text { Total }\end{array}$ & 7380.488 & 79 & & & & & & \\
\hline
\end{tabular}

Berdasarkan Tabel 3 angka signifikansi pada lajur model pembelajaran menunjukkan angka signifikansi sebesar 0,000 . Angka signifikansi tersebut lebih kecil dari 0,05 , sehingga sehingga dapat diambil keputusan $\mathrm{H}_{0}$ ditolak dan dapat disimpulkan bahwa terdapat perbedaan hasil belajar IPA antara siswa yang dibelajarkan dengan model pembelajaran GI berbantuan Virtual Laboratory dan model pembelajaran Direct Instruction.

Hasil tindak lanjut LSD menunjukkan bahwa hasil belajar IPA siswa yang belajar dengan model pembelajaran kooperatif tipe Gl berbantuan media virtual laboratory relatif lebih tinggi dibandingkan model pembelajaran Direct Instruction (LSD = 8,032; $\Delta \mu=8,484)$.

\section{PEMBAHASAN}

Penelitian ini dilakukan untuk menjelaskan pengaruh hasil belajar siswa yang dibelajarkan dengan menggunakan model pembelajaran kooperatif tipe Group Investigation (Gl) berbantuan media virtual laboratory dan model pembelajaran Direct Instruction (DI). Model Gl dipilih dalam pembelajaran dikarenakan dalam model pembelajaran ini siswa dituntut bekerja secara aktif dalam kelompok kecil untuk melaksanakan investigasi/penyelidikan terhadap suatu permasalahan melalui praktikum untuk mencari atau memahami informasi sehingga dapat digunakan untuk memecahkan suatu permasalahan yang dihadapi siswwa. Virtual laboratory digunakan sebagai media alternatif pengganti peran laboratorium sesungguhnya untuk mengatasi terbatasnya laboratorium di sekolah. Sampel pada penelitian ini terdiri dari dua kelompok, yaitu kelompok siswa yang dibelajarkan dengan menggunakan model Gl sebagai kelas eksperimen (kelas VIIIA dan VIIIB), dan kelompok siswa yang dibelajarkan dengan menggunakan model DI sebagai kelas kontrol (kelas VIIIC dan VIIID). Model GI dibagi menjadi enam tahap, yaitu tahap pertama mengidentifikasi topik dan mengatur siswa dalam kelompok. Pada tahap ini, guru membagi siswa menjadi beberapa kelompok yang beranggotakan 4 sampai 5 siswa secara heterogen. Guru kemudian mengarahkan siswa untuk memilih topik yang akan dipelajari. Dalam kegiatan pembelajaran ini, topik pembelajaran ditentukan oleh guru.

Tahap kedua yaitu merencanakan tugas yang akan dipelajari. Pada tahap ini, siswa diarahkan untuk menyusun suatu 
rencana pembelajaran sesuai dengan subtopik yang dipilih. Siswa mendiskusikan tugas yang akan dikerjakan dari masingmasing anggota kelompok.

Tahap ketiga yaitu melaksanakan investigasi. Pada tahap ini, siswa mulai melaksanakan rencana yang telah disusun atau dibuat. Guru menyiapkan media virtual laboratory dan petunjuk penggunaan media, serta LKPD untuk menunjang siswa dalam kegiatan diskusi sehingga siswa dapat mengumpulkan informasi sesuai dengan subtopik yang dipilih. Namun, jika investigasi dalam subtopik tertentu dapat dilakukan tanpa peralatan dan bahan-bahan yang hanya tersedia di laboratorium, maka penggunaan media virtual laboratory tidak diperlukan. Dengan media yang telah disiapkan oleh guru, siswa mulai mengumpulkan informasi dengan panduan LKPD sehingga siswa dapat menemukan hasil atau jawaban dari pemasalahan yang dirumuskan sebelumnya. Setelah itu siswa mulai mencatat informasi yang didapatkan untuk disajikan pada tahap penyajian akhir.

Tahap keempat yaitu menyiapkan laporan akhir. Pada tahap ini, siswa mulai menganalisis dan menyintesis informasi yang didapatkan serta mendiskusikannya dengan seluruh anggota kelompok. Hasil dari kegiatan analisis dan sintesis akan dicatat dan disajikan di depan kelas secara berkelompok pada kegiatan diskusi kelas.

Tahap kelima yaitu
mempresentasikan laporan akhir. Pada tahap ini, masing-masing kelompok akan mempresentasikan hasil diskusi kelompoknya di depan kelas untuk mendapat tanggapan dari kelompok lain. Siswa diharapkan terlibat secara aktif dalam diskusi baik itu dalam penyampaian tanggapan, bertanya dan lain sebagainya. Pada penyajian akhir ini, guru memfasilitasi siswa agar siswa memperoleh konsep yang benar.

Tahap keenam yaitu evaluasi. Pada tahap terakhir ini, guru akan mengukur seberapa jauh pemahaman siswa tentang materi yang telah dipelajari dengan memberikan posttes kepada masing-masing siswa sehingga guru akan mengetahui seberapa jauh pemahaman siswa tentang materi yang telah dipelajari.
Kelompok siswa pada model pembelajaran DI menerima langsung materi pelajaran dari guru baik berupa konsep ataupun keterampilan yang meliputi, penyajian materi, pemberian contoh konsep, demonstrasi materi, dan menjelaskan kembali hal yang dianggap sulit atau kurang dimengerti oleh siswa. LKPD yang diberikan pada kelas kontrol berbeda dengan kelas eksperimen, karena praktikum yang dilakukan di kelas kontrol adalah praktikum sederhana yang dalam prosesnya dapat menggunakan alat dan bahan sederhana yang mudah ditemui oleh siswa ataupun sudah tersedia di sekolah. Pada kelompok siswa yang mendapat perlakuan model pembelajaran DI akan mengerjakan LKPD secara berkelompok dan hasil diskusi ini disampaikan di depan kelas oleh perwakilan salah satu kelompok.

Hasil penelitian ini menunjukkan bahwa skor rata-rata hasil belajar IPA siswa kelas VIII yang dibelajarkan menggunakan model GI berbantuan media virtual laboratory relatif lebih tinggi dibandingkan dengan siswa yang dibelajarkan dengan menggunakan model DI. Rata-rata hasil belajar kelas eksperimen dan kelas kontrol masing-masing sebesar 80,17 dan 73,67 dengan standar deviasi masing-masing sebesar 8,674 dan 9,187. Selain itu, distribusi frekuensi skor posttest siswa pada kelas eksperimen memiliki sebaran skor yang lebih baik daripada kelas kontrol. Hal ini dapat dilihat dari frekuensi sebaran perolehan skor posttest siswa pada kelas eksperimen yang memiliki kualifikasi sangat baik sebanyak 12,5\%, kualifikasi baik sebanyak 35\%, kualifikasi cukup baik sebanyak 47,5\%, dan kualifikasi kurang sebesar 5,0\%. Sedangkan pada kelas kontrol distribusi frekuensi skor posttest siswa yang berkualifikasi sangat baik hanya sebesar 10,0\%, kualifikasi baik sebesar $25,0 \%$, kategori cukup baik sebesar $55,0 \%$, dan kategori kurang sebesar 10,0\%.

Hasil analisis kovarian pada penelitian ini menunjukkan bahwa antara model pembelajaran Gl berbantuan media virtual laboratory dan model pembelajaran DI terdapat perbedaan yang signifikan pada hasil belajar siswa. Hal ini dapat ditunjukkan 
dengan skor statistik $F=13,859$ dengan angka signifikansi 0,000 . Angka signifikansi ini lebih kecil dari 0,05. Jadi, hasil belajar siswa secara signifikan $(p<0,05)$ dipengaruhi oleh model pembelajaran yang digunakan dalam pembelajaran. Berdasarkan hasil analisis yang diperoleh menunjukkan bahwa model pembelajaran kooperatif tipe Gl berbantuan media virtual laboratory lebih baik diterapkan dibandingkan dengan model pembelajaran DI dalam upaya meningkatkan hasil belajar siswa.

Hasil tindak lanjut LSD menunjukkan bahwa signifikansi rata-rata hasil belajar siswa yang belajar dengan model pembelajaran kooperatif tipe Gl berbantuan media virtual laboratory lebih tinggi dibandingkan model pembelajaran DI (LSD = 8,032; $\Delta \mu=8,484)$. Hal tersebut berarti pengaruh model pembelajaran kooperatif tipe GI berbantuan media virtual laboratory terhadap hasil belajar siswa secara statistik lebih baik dibandingkan dengan pengaruh model pembelajaran DI terhadap hasil belajar siswa.

Hasil penelitian ini telah membuktikan hipotesis yang diajukan, yaitu terdapat pengaruh model pembelajaran kooperatif tipe GI berbantuan media virtual laboratory terhadap hasil belajar IPA, yang secara spesifik ditunjukkan oleh terdapatnya perbedaan hasil belajar siswa antara kelompok siswa yang belajar menggunakan model pembelajaran kooperatif tipe Gl dengan siswa yang belajar dengan menggunakan model pembelajaran DI. Jadi, hasil belajar siswa pada kelompok siswa yang belajar menggunakan model pembelajaran kooperatif tipe Gl lebih baik dibandingkan dengan hasil belajar pada kelompok siswa yang belajar dengan menggunakan model pembelajaran DI. Hal ini disebabkan karena ketika menjalankan pembelajaran kooperatif GI, siswa berperan aktif dalam melakukan investigasi untuk membuktikan suatu fenomena atau memecahkan masalah yang bersifat kompleks. Siswa terlebih dahulu ditugaskan bersama dengan anggota kelompoknya untuk menggali informasi tentang materi dari suatu fenomena atau permasalahan dari berbagai sumber yang relevan. Melalui kegiatan penyelidikan, siswa dapat membuktikan fenomena yang telah dipahaminya sehingga akan mendatangkan keyakinan akan kebenaran suatu materi. Keterlibatan siswa mulai dari merencanakan, mengumpulkan data, mengolah data, dan menarik kesimpulan akan memperkuat ingatannya terhadap suatu materi. Dengan demikian, pembelajaran yang dilakukan akan lebih bermakna sehingga pemahaman yang didapatkan siswa akan mempengaruhi hasil belajar siswa. Penggunaan media virtual laboratory dalam membantu proses kegiatan belajar juga merupakan hal yang baru bagi siswa sehingga pembelajaran yang dilalui siswa menjadi lebih menyenangkan karena tingginya antusiasme siswa dalam mengikuti kegiatan belajar.

Temuan-temuan dalam penelitian ini sejalan dengan hasil penelitian yang telah dilaksanakan pada penelitian sebelumnya, terkait dengan model pembelajaran kooperatif tipe GI berbantuan media virtual laboratory. Astiti (2018) menyatakan bahwa penggunaan model pembelajaran kooperatif tipe Gl membuat siswa lebih aktif dalam mengikuti pelajaran, karena siswa dilibatkan secara langsung dalam pemilihan topik yang akan didiskusikan dan dipelajari lebih lanjut. Siswa merasa bebas untuk berkontribusi pada topik yang dibahas. Selain itu, siswa merasa lebih antusias karena mereka akan mempelajari topik yang diminatinya sehingga siswa tidak merasa terbebani. Pada tahap pembagian kelompok, siswa juga diberikan tanggung jawab dalam kelompok. Pada tahap penyelidikan setelah siswa berada di kelompok masing-masing, siswa akan bebas dalam menciptakan dan membangun pemahamannya sendiri sehingga kepercayaan diri juga akan meningkat. Siswa yang bekerja dalam kelompok akan berlatih untuk bekerja bersama melalui kegiatan diskusi. Pada tahap diskusi, setiap siswa diminta untuk menyatakan pendapatnya sehingga siswa akan terbiasa berbicara secara sistematis.

Penggunaan model pembelajaran kooperatif tipe Gl dapat meningkatkan kompetensi pengetahuan peserta didik. Kegiatan-kegiatan investigasi dalam 
praktikum membantu peserta didik memperoleh pengetahuan yang bermakna. Penggunaan media virtual laboratory dalam kegiatan praktikum menjadi hal baru bagi peserta didik sehingga mereka mengikuti kegiatan praktikum dengan antusias (Kurnia, 2017). Nova Irwan (2015) dalam penelitiannya menyebutkan bahwa hasil belajar siswa yang dibelajarkan dengan model kooperatif tipe Gl lebih tinggi dibandingkan dengan siswa yang dibelajarkan dengan model Direct Instruction.

Sebuah penelitian tentu tidak akan lepas dari kendala-kendala yang dapat menghambat proses penelitian. Peneliti menemukan beberapa kendala yang dihadapi mulai dari pelaksanaan uji coba instrumen sampai pada pemberian posttest, yaitu sebagai berikut.

Pertama, sulitnya mendapatkan sekolah tempat melakukan uji coba instrumen tes hasil belajar karena pada penelitian ini pokok bahasan yang digunakan adalah tekanan pada zat dan penerapannya dalam kehidupan sehari-hari yang diperoleh di kelas VIII semester genap, sehingga uji coba instrumen penelitian harus dilakukan di kelas IX. Sementara di sekolah-sekolah pada bulan Februari 2018, kelas IX sudah mulai melaksanakan pemantapan persiapan UN sehingga pihak sekolah merasa tidak tepat untuk memberikan izin melaksanakan uji coba instrumen di kelas IX. Kendala inipun dapat ditanggulangi dengan berkoordinasi secara baik dengan pihak sekolah dan akhirnya peneliti mendapat izin melaksanakan uji coba instrumen di MTs Negeri 2 Buleleng pada kelas XI A, IX B, XI C, dan IX D.

Kedua, pada proses pembelajaran terkendala dengan tidak adanya LCD dan proyektor, serta tidak terdapat akses internet pada masing-masing kelas sehingga peneliti sulit untuk menayangkan media powerpoint dan virtual laboratory. Namun peneliti menanggulangi masalah tersebut dengan membuat powerpoint dalam bentuk print out dan membagikannya pada masing-masing kelompok siswa. Peneliti juga mengimbau siswa yang memiliki laptop agar membawa satu laptop pada setiap kelompok pada saat dilaksanakan model pembelajaran GI berbantuan media virtual laboratory. Untuk akses internet, petunjuk penggunaan media virtual laboratory dan LKPD telah peneliti sediakan, sehingga proses investigasi kelompok dapat berjalan dengan baik dan lancar.

Hasil penelitian telah menunjukkan bahwa hasil belajar siswa pada kelompok eksperimen yang diberikan model pembelajaran kooperatif tipe Gl lebih tinggi dibandingkan dengan kelompok kontrol yang diberikan model pembelajaran DI. Keberhasilan suatu pembelajaran tergantung pada kemampuan guru untuk mengelola kelas dan memilih model pembelajaran yang tepat untuk digunakan. Oleh karena itu, penerapan model pembelajaran kooperatif tipe Gl berbantuan media virtual laboratory dalam proses pembelajaran dimaksudkan untuk membiasakan siswa untuk bekerja aktif secara berkelompok, sebaliknya dengan menggunakan model pembelajaran DI membuat siswa kurang dapat mengembangkan pola berpikirnya karena hanya guru yang aktif dalam proses pembelajaran. Implikasinya adalah guru harus dapat memilih suatu model pembelajaran yang sesuai dengan karakter siswa, salah satunya dengan menerapkan model pembelajaran Gl berbantuan media virtual laboratory.

\section{SIMPULAN DAN SARAN}

Berdasarkan hasil penelitian dan pembahasan dapat ditulis simpulan bahwa terdapat perbedaan hasil belajar IPA siswa kelas VIII MTs Negeri 2 Buleleng pada materi tekanan zat dan penerapannya dalam kehidupan sehari-hari antara kelompok siswa yang mengikuti model pembelajaran kooperatif tipe Group Investigation (GI) berbantuan media virtual laboratory dengan kelompok siswa yang mengikuti model pembelajaran Direct Instruction ( $F=13,859$ dengan angka signifikansi 0,000).

Hasil tindak lanjut LSD menunjukkan bahwa hasil belajar IPA siswa yang belajar dengan model pembelajaran kooperatif tipe GI berbantuan media virtual laboratory relatif lebih tinggi dibandingkan model 
pembelajaran Direct Instruction (LSD = 8,032; $\Delta \mu=8,484$ ).

Berdasarkan hasil penelitian dapat diajukan beberapa saran guna meningkatkan kualitas pembelajaran IPA. (1) hasil penelitian menunjukkan bahwa siswa yang belajar dengan model pembelajaran kooperatif tipe Gl secara signifikan memperoleh hasil belajar IPA yang lebih baik daripada siswa yang menggunakan model pembelajaran Direct Instruction. Oleh karena itu, model pembelajaran kooperatif tipe Gl dapat digunakan sebagai salah satu alternatif strategi pembelajaran yang dapat digunakan di sekolah karena sesuai dengan paradigma konstruktivisme. (2) materi pembelajaran yang digunakan dalam penelitian ini terbatas hanya pada pokok bahasan tekanan pada zat dan penerapannya dalam kehidupan sehari-hari sehingga dapat dikatakan bahwa hasil-hasil penelitian terbatas hanya pada materi tersebut. Oleh karena itu, peneliti menyarankan untuk diadakan penelitian lebih lanjut terkait dengan model pembelajaran kooperatif tipe Gl dalam pembelajaran IPA untuk mengetahui kemungkinan hasil yang berbeda. penelitian ini hanya difokuskan untuk menyelidiki pengaruh model pembelajaran kooperatif tipe GI terhadap hasil belajar IPA saja. Oleh karena itu, peneliti menyarankan untuk diadakan penelitian lebih lanjut terkait pengaruh model pembelajaran kooperatif tipe GI dalam pembelajaran IPA terhadap variabel-variabel lain misalnya aspek kinerja ilmiah siswa, aspek kemampuan berpikir kritis siswa, aspek kemampuan pemecahan masalah siswa, dan lain sebagainya. (4) penelitian ini hanya menggunakan siswa kelas VIII MTs Negeri 2 Buleleng tahun pelajaran 2017/2018 sebagai populasi sehingga generalisasi terhadap hasil penelitian ini masih cukup terbatas. Oleh karena itu, peneliti menyarankan untuk diadakan penelitian lebih lanjut terkait pengaruh model pembelajaran kooperatif tipe GI dalam pembelajaran IPA dengan menggunakan populasi yang lebih banyak dan bervariasi dilihat dari jumlah sekolah yang digunakan. (5) model pembelajaran kooperatif tipe Gl dapat menciptakan suasana pembelajaran aktif, kreatif, efektif, dan menyenangkan apabila didukung oleh media pembelajaran yang relevan seperti media virtual laboratory. Untuk itu, disarankan kepada guru untuk menggunakan media virtual laboratory sebagai media alternatif dalam menciptakan suasana pembelajaran yang dapat membantu peserta didik mengoptimalkan potensi dirinya. (6) penelitian kedepannya disarankan agar lebih memperlihatkan dan mengendalikan faktor-faktor lain yang dapat mempengaruhi hasil belajar, seperti motivasi, IQ, kemampuan berpikir formal, dan sebagainya. Hal ini karena penelitian ini hanya mengendalikan kovariat pengetahuan awal yang mengukur sejauh mana pengetahuan siswa terhadap suatu materi sebelum diberikan perlakuan berdasarkan pengalaman siswa.

\section{DAFTAR PUSTAKA}

Alawiyah, Faridah. 2013. Peran Guru dalam Kurikulum 2013. Jurnal Aspirasi. Volume 4, Nomor 1. Tersedia pada http://jurnal.dpr.go.id/index.php/aspir asi/article/view/480. Diakses pada tanggal 5 Januari 2018.

Astiti, Kadek Ayu .2018. The Effect of Group Investigation (GI) Learning Model with Brainstorming Technique on Student Learning Outcomes. SHS Web of Conferences. Volume 42, Nomor 122. Tersedia pada: https://www.shs-

conferences.org/articles/shsconf/abs/ 2018/03/shsconf gctale2018 00122/ shsconf_gctale2018_00122.html. Diakses pada tanggal 19 Juni 2018.

Balitbang. 2015. Laporan Hasil TIMSS 2015. Jakarta: Kemendikbud. Tersedia pada http://litbang.kemendikbud.go.id/inde x.php/survei-internasional-timss. Diakses pada tanggal 2 April 2018.

Depdiknas. 2006. Permendiknas Nomor 22 Tahun 2006 Tentang Standar Isi. Jakarta: Depdiknas. 
Depdiknas. 2003. Undang-Undang Republik Indonesia Nomor 20 Tahun 2003 Tentang Sistem Pendidikan Nasional. Jakarta: Depdiknas.

Irwan, Nova 2015. Efek Model Pembelajaran Kooperatif Tipe Group Investigation (Gl) dan Teamwork Skills Terhadap Hasil Belajar Fisika. Jurnal Pendidikan Fisika. Volume 4, Nomor 1. Tersedia pada http://jurnal.unimed. ac.id/2012/index.php/jpf/article/viewF ile/Nova\%20lwan\%20dan\%20Ridwa n\%20A.\%20Sani/2264. Diakses pada tanggal 4 April 2018.

Isjoni. 2009. Cooperative Learning Efektifitas Pembelajaran Kelompok. Jakarta: Alfabeta.

Kemdikbud. 2017. Rekapitulasi Hasil Ujian Nasional IPA SMP/MTs SeKabupaten Buleleng. Tersedia pada https://bulelengkab.go.id/bankdata/h asilujian nasionalipa.html. Diakses pada tanggal 20 Desember 2017.

Kurnia, Wahyu. 2017. Pengaruh Penerapan Virtual Lab Berbantuan LKPD Menggunakan Model Pembelajaran Kooperatif Tipe Group Investigation Terhadap Kompetensi Peserta Didik Kelas XI SMA N 5 Padang. Pillar of Physics Education. Volume 10 (Halaman. 161-168). Tersedia pada http://ejournal.unp.ac.id/students/ind ex.php/pfis/article/view/2572.

Diakses pada tanggal 4 April 2018.

Maryani, Ika. 2010. Pembelajaran Kooperatif GI (Group Investigation) Berbantuan Media Laboratorium Virtual Dilengkapi Handout untuk Meningkatkan Kualitas Proses dan Hasil Belajar Kimia. Skripsi Fakultas Keguruan dan IImu Pendidikan Universitas Sebelas Maret Surakarta. Tersedia pada https://eprints.uns.ac.id/3272/.

Diakses pada tanggal 8 Mei 2018.
Muhibbin Syah. 2010. Psikologi Pendidikan dengan Pendekatan Baru. Bandung: PT Remaja Rosdakarya.

Nisrina, Nina .2016. Pembelajaran Kooperatif dengan Media Virtual untuk Peningkatan Penguasaan Konsep Fluida Statis Siswa. Jurnal Pendidikan Fisika dan Teknologi. Volume 2, Nomor 2. Tersedia pada https://media.neliti.com/media/public ations/119707-ID-pembelajaran kooperatif-dengan.media-vir.pdf. Diakses pada tanggal 8 Mei 2018.

OECD. 2016. PISA 2015 Result: What Studnets Know and Can Do-Student Performance in Mathematics, Reading and Science. http://www. oecd.org/pisa/keyfindings/pisa-2015results.html. Diakses pada tanggal 12 Desember 2017

Sanjaya, Wina. 2012. Strategi Pembelajaran Berorientasi Standar Proses Pendidikan. Jakarta: Kencana Prenada Media Grup.

Slavin, Robert E. 2006. Psikologi Pendidikan Teori dan Praktek Edisi Kesembilan Jilid 1. Jakarta: PT Indeks.

Sugiyono. 2013. Metode Penelitian Pendidikan (Pendekatan Kuantitatif, Kualitatif, dan R\&D). Bandung: Alfabeta. 